\title{
Post-traumatic eyeball luxation
}

\section{Avulsión postraumática de globo ocular}

\author{
Fernando Munayco-Guillén ${ }^{1,2 *}$, Pedro Muro-Mansilla ${ }^{1,3}$, Jose Velasco-Stoll ${ }^{1}$, Jose A. Zavala-Loayza ${ }^{1}$ and \\ Ramón R. Cámara-Reyes ${ }^{4}$ \\ ${ }^{1}$ National Institute of Ophthalmology “Dr. Francisco Contreras Campos", Lima; ${ }^{2}$ University of San Martín de Porres, Lima; ${ }^{3}$ Cayetano Heredia Peruvian \\ University, Lima; ${ }^{4}$ Scientific Society of Medical Students of Ica (SOCEMI), San Luis Gonzaga University, Ica. Peru
}

\begin{abstract}
Eyeball luxation is an uncommon complication of high-impact trauma to the face, orbit, or skull. This is the case of a 20-yearold male who suffered an accident while driving a motorcycle drunk. He points out that he hit his face and his right eye. He denies losing consciousness, but he notices sudden loss of vision in the right eye. Physical examination revealed eyeball luxation from the orbit, with disinsertion of the medial and inferior rectus muscle. Visual acuity was no light perception in his right eye. He has a history of craniotomy due to a prior head injury 4 years ago. A computed tomography showed eyeball absence in the right orbit, without fracture or cerebral edema. In the operating room, an eyeball luxation was confirmed, with partial section of the extraocular muscles and complete avulsion of the optic nerve. We describe several mechanisms that may explain the eyeball luxation.
\end{abstract}

Key words: Post traumatic luxation. Post traumatic enucleation. Facial trauma. Head trauma. Ocular trauma. Eye luxation.

\section{Resumen}

La avulsión del globo ocular es una complicación infrecuente de un trauma de alta energía de la cara, órbita o cráneo. Paciente varón de 20 años en estado etílico sufre un accidente de tránsito en una motocicleta. Señala que se golpeó la cara y el ojo derecho. Niega haber perdido la conciencia, pero nota la pérdida súbita de visión en su ojo derecho. Al examen físico se aprecia el globo ocular luxado de la órbita, con desinserción del músculo recto medial e inferior. Presenta una agudeza visual de no percepción de luz. Antecedente de una craneotomía por un traumatismo craneoencefálico hace 4 años. Se le realiza tomografía computarizada que señala la ausencia del globo ocular derecho en la cavidad orbitaria y no hay fractura ni edema cerebral. Se retira el ojo y se confirmó la luxación total del globo ocular, los músculos extraoculares estaban parcialmente seccionados y el nervio óptico, totalmente seccionado. Se describen diversos mecanismos que explican la salida del globo ocular.

Palabras clave: Avulsión postraumática. Enucleación postraumática. Trauma facial. Trauma craneal. Trauma ocular. Luxación ocular.

Av. Antonio José de Sucre, 420, Dept. $306 \quad$ Date of reception: 24-03-2018

Pueblo Libre, Lima, Peru

E-mail: fernandomg345@ hotmail.com

DOI: 10.24875/RMOE.M20000098
Available online: 01-03-2020

Date of acceptance: 11-09-2018
Rev Mex Oftalmol (Eng). 2020;94(2):81-84

www.rmo.com.mx (http://creativecommons.org/licenses/by-nc-nd/4.0/) 


\section{Introduction}

The term avulsion means "forced extraction". Post traumatic avulsion of the eyeball is a very rare clinical condition. It is associated with facial and cranial trauma ${ }^{1}$.

It is classified as incomplete avulsion, when it affects only the optic nerve, and complete avulsion, when it involves the optic nerve and the extraocular muscles ${ }^{2,3}$.

According to Morris, there are three possible mechanisms: a) an object that enters the orbit and exerts the function of a wedge or lever that displaces the eyeball; b) fractures of the bone of the orbit that displace the globe, and c) abrupt deceleration. There are other mechanisms such as narrowing of the orbit due to fracture, orbital hemorrhage ${ }^{4}$.

Our objective is to describe a case of post traumatic avulsion of the eyeball after facial and skull trauma, and to discuss the most appropriate management.

\section{Case presentation}

\section{Clinical case}

This is a 20-year-old male patient who, while intoxicated, suffered a traffic accident riding as a passenger on the back of a motorcycle. The patient explained that he hit his face and right eye and presented sudden loss of vision in this eye. He did not report loss of consciousness.

The patient was assisted and taken to a general hospital where he was examined by a neurosurgeon, who clinically and by images (CT scan of the skull and orbits) did not find signs of fracture or cerebral edema, and diagnosed a neurologically stable patient with a Glasgow of $15 / 15$, so he decided to refer the patient to our institution for an ophthalmological evaluation. An MRI was not performed due to economic reasons and because the patient did not have medical insurance.

The patient arrived at our institution approximately 15 hours after the event. Examination showed an intact right eyeball located outside the orbital cavity (Figs. 1 and 2). There was corneal edema (+) that allowed to visualize details of the anterior chamber, observing a semi-dilated pupil that does not react to light. The fundus was not evaluable due to the presence of vitreous hemorrhage. A total disintegration of the medial and inferior rectus muscles was also observed.

$\mathrm{He}$ had a visual acuity in the right eye of no light perception and of 20/30 in the left eye. We decided

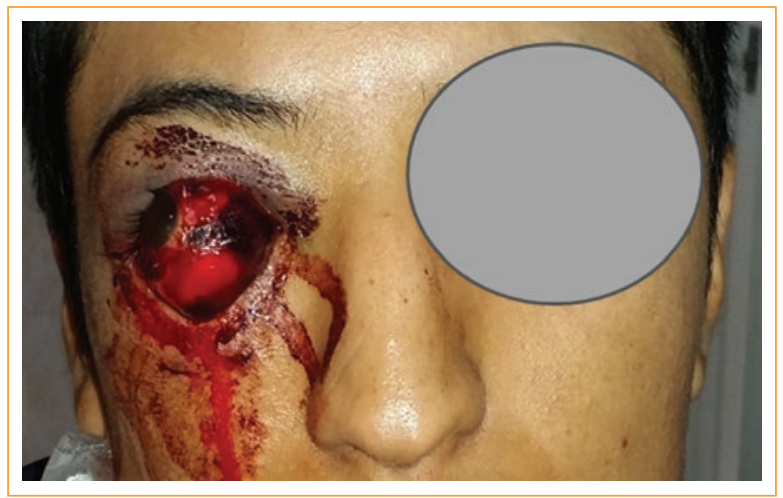

Figure 1. Post traumatic avulsion of the right eyeball. Note the fully lateralized cornea towards the temporal side.

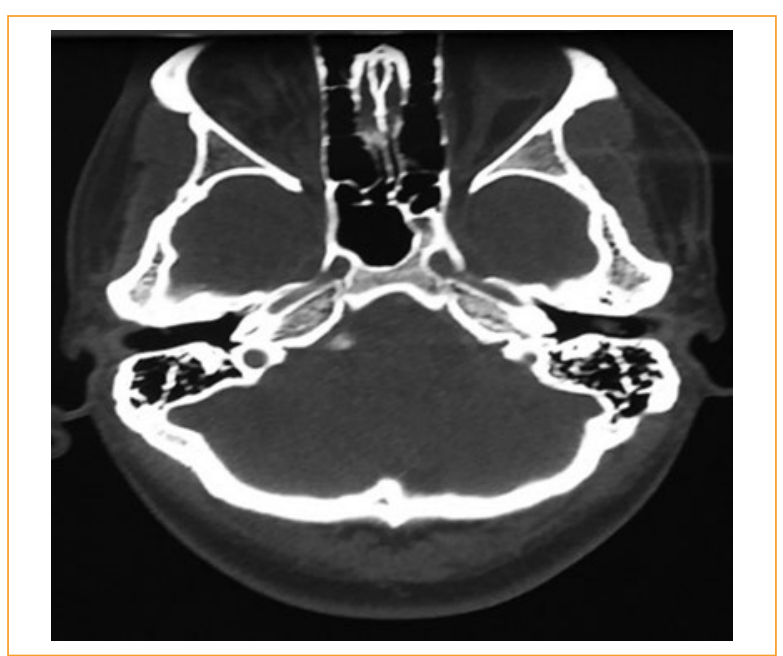

Figure 2. Tomography showing the absence of the right globe in the orbit, without evidence of orbital fractures.

to perform a surgical examination to assess the anatomical damage and evaluate the possibility of repositioning the globe in the orbit. We found that the optic nerve was sectioned together with the posterior short ciliary arteries, and that the eyeball only had collateral circulation from the extraocular muscles, so it was decided to complete the enucleation (Figs. 3 and 4). When evidencing the total section of the medial and inferior rectus and the extensive damage to the ocular surface, the possibility of exposure and extrusion of an implant was considered high, so we decided not to place it (Fig. 4).

The sample was sent to the ocular pathology laboratory, that reported the presence of fibrin in the anterior chamber, synechiae between the iris and the lens, ciliary body detachment, choroidal and suprachoroidal 


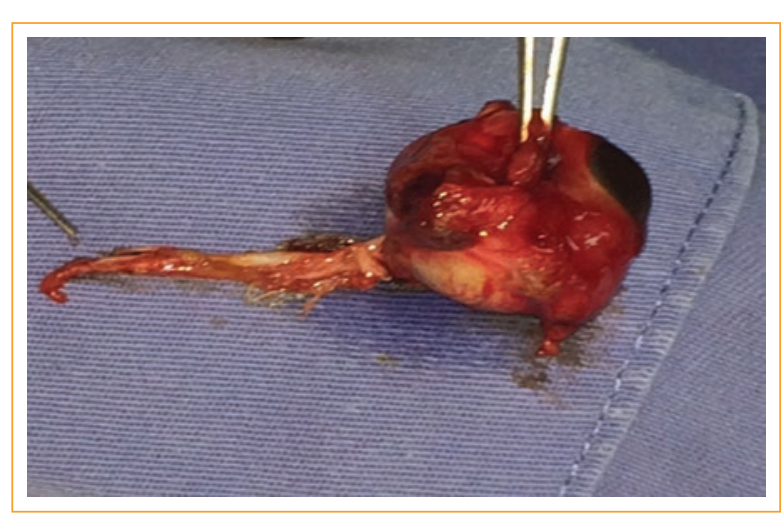

Figure 3. Avulsed globe with a 25-mm optic nerve portion.

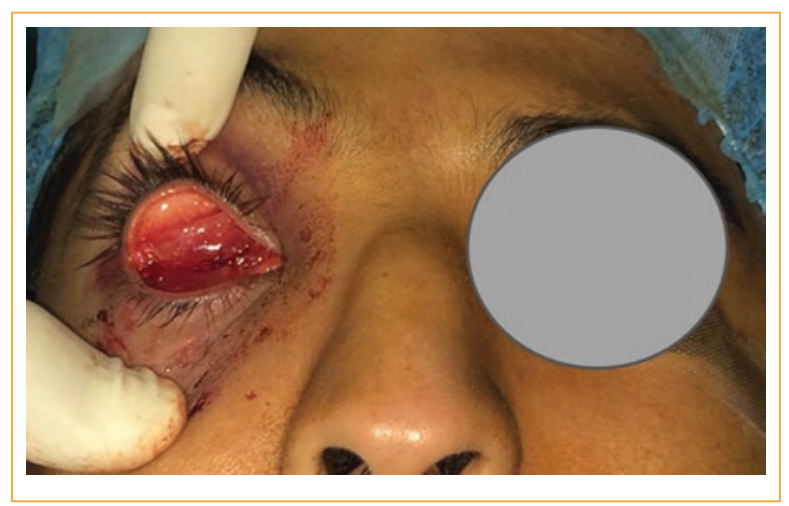

Figure 4. The patient after enucleation.

hemorrhage, dense vitreous hemorrhage, retinal necrosis, optic atrophy and meninges without optic nerve.

\section{Discussion}

Post traumatic avulsion of the eyeball is a very rare clinical condition and is usually related to maxillofacial trauma ${ }^{1,2}$. In our case there were no orbital or skull fractures, according to tomographic images.

Every patient with avulsion of the optic nerve and dislocation of the eyeball after trauma, must undergo a complete neurological clinical examination that includes a tomographic and magnetic resonance control. It is recommended to start broad-spectrum antibiotic therapy to prevent infections ${ }^{1,3}$.

Depending on the anatomical and visual status of the eyeball, there should be an attempt to reposition it in the orbit for aesthetic and psychological reasons. Eyeball repositioning depends on the functional state of the eye, the anatomical integrity of the eyeball, the presence of infections, the vascular state of the eye, the vitality of ocular tissues and the presence of pain ${ }^{4,5}$.
Repositioning the eyeball in the orbit allows the patient to avoid the feeling of mutilation, achieving a better aesthetic result. In the case of children, it favors and stimulates orbital development ${ }^{6,7}$.

Although in some cases the eyeball may evolve to phthisis bulbi, it has been observed that with time, patients are more likely to accept evisceration to improve their aesthetic appearance ${ }^{7}$. If the damage did not fully affect the ophthalmic artery, the eyeball will hardly evolve to phthisis bulbi?

The literature indicates that, in this type of trauma, the order of avulsion of the extraocular muscles by frequency is medial rectus, inferior rectus, lateral rectus and obliques ${ }^{5,6,8}$. In our patient, this data is consistent.

Considering the mechanisms of trauma, our patient reported that no foreign object was introduced into his orbit, so we presume that one of the main mechanisms was abrupt deceleration, as described by Song and Carter ${ }^{6}$.

\section{Conclusions}

Post traumatic avulsion of the eyeball is a very rare clinical condition usually related to trauma of maxillofacial structures.

These patients should be evaluated comprehensively from the perspective of each specialty: neurology, ophthalmology, head and neck surgery.

Depending on the anatomical and visual status of the eyeball, there should be an attempt to reposition the globe in the orbit to achieve aesthetic and psychological benefits.

\section{Conflicts of interest}

The authors declare no conflict of interests.

\section{Funding}

This article was self-funded.

\section{Ethical disclosures}

Protection of human and animal subjects. The authors declare that no experiments were performed on humans or animals for this study.

Confidentiality of data. The authors declare that they have followed the protocols of their work center on the publication of patient data. 
Rev Mex Oftalmol (Eng). 2020;94(2)

Right to privacy and informed consent. The authors have obtained the written informed consent of the patients or subjects mentioned in the article. The corresponding author is in possession of this document.

\section{References}

1. Gupta R. Traumatic complete evulsion of the globe and optic nerve. Can J Ophthalmol. 2014;49(5):110-2.

2. Pillai S, Mahmood M, Limay S. Complete evulsion of the globe and optic nerve. $\mathrm{Br}$ J Ophthalmol. 1987;71:69-72.
3. De Santana Santos T, Vajgel A, Ribeiro CF, de Santana Júnior JR, Andrade Filho ES. Avulsion of globe following maxillofacial trauma. J Craniofac Surg. 2012;23(4):1097-100.

4. Figueiredo-Amaral M, Furtado-Carvalho M, Baptista-Ferreira A, Alves-Mesquita R. Traumatic globe luxation associated with orbital fracture in a child: A case report and literature review. J Maxillofac Oral Surg. 2015;4(1):323-30.

5. Kumari E, Chakraborty S, Ray B. Traumatic globe luxation: A case report Indian J Ophthalmol. 2015;63:682-4.

6. Kelahmetoğlu O, Şimşek T, Beden U. Rarely seen complication of moto vehicle accidents: Bilateral globe avulsión. Turk J Trauma Emerg Surg. 2015;21(4):297-9.

7. Ersan I, Adam M, Oltulu R, Zengin, Okka M. Traumatic luxation of the globe: A 6-year follow-up. Orbit. 2016;35(2):69-71.

8. Tok L, Tok OY, Argun T, Yilmaz O, Alime G, Elif U, et al. Bilateral traumatic globe luxation with optic nerve transection. Case Rep Ophthalmol. 2014;5:429-34. 